Drought response and changing mean sensitivity of European beech close to the dry distribution limit

\author{
Journal Article \\ Author(s): \\ Weber, P.; Bugmann, H.; Pluess, A. R.; Walthert, L.; Rigling, A. \\ Publication date: \\ 2013-02 \\ Permanent link: \\ https://doi.org/10.3929/ethz-b-000064060 \\ Rights / license: \\ In Copyright - Non-Commercial Use Permitted \\ Originally published in: \\ Trees 27(1), https://doi.org/10.1007/s00468-012-0786-4
}




\title{
Drought response and changing mean sensitivity of European beech close to the dry distribution limit
}

\author{
P. Weber · H. Bugmann • A. R. Pluess $\cdot$ \\ L. Walthert $\cdot$ A. Rigling
}

Received: 8 June 2012/Revised: 6 September 2012/ Accepted: 25 September 2012/Published online: 10 October 2012

(c) Springer-Verlag Berlin Heidelberg 2012

\begin{abstract}
European beech (Fagus sylvatica L.) covers a large area mainly in the colline and montane ranges in Europe, and a drier and warmer climate, as expected for the coming decades, is likely to alter its distribution. So far, an altitudinal shift has been projected using a variety of modelling approaches. However, we lack knowledge about the climatic and edaphic factors that control the growth and competitive behaviour of beech at its dry distribution limit. We applied and further developed dendroecological methods to study the drought response and sensitivity pattern of beech at sites with different moisture regimes. We compared three pairs of sites from different geographical regions near the dry distribution limit of beech in Switzerland, consisting of a dry and mesic site each. Radial growth differed between mesic and dry sites, in that average ring-width at mesic sites was around double the width at dry sites. For the whole study period (1930-2006), the sites with the lowest available soil water capacity (AWC) were found to respond most sensitively to drought. However, in recent years, sites with higher AWC have shown increasing drought sensitivity, i.e. they have responded even more strongly to drought than the dry sites.
\end{abstract}

Communicated by H. Rennenberg.

P. Weber $(\bowtie) \cdot$ L. Walthert · A. Rigling

Swiss Federal Research Institute WSL,

Birmensdorf, Switzerland

e-mail: pascale.weber@alumni.ethz.ch

H. Bugmann

Forest Ecology, Institute of Terrestrial Ecosystems,

ETH Zürich, Zurich, Switzerland

A. R. Pluess

Ecosystem Management, Institute of Terrestrial Ecosystems,

ETH Zürich, Zurich, Switzerland
This change in sensitivity corresponds to a seasonal shift in drought response at mesic sites, with a change in the months showing significant drought response in all three studied regions compared with the past. Even though dry sites generally displayed a larger number of negative pointer years than mesic sites, it appears that the frequency of pointer years has increased at mesic sites, i.e. they have become more sensitive particularly in the last quarter of the twentieth century. Yet, the frequency of pointer years at the dry sites has remained fairly constant. These results indicate that beech trees near their dry distribution limit are adapted to extreme conditions already, while changes in the growth patterns of beech under mesic conditions have to be expected.

Keywords Fagus sylvatica - Distribution range . Dendroecology · Drought response · Soil moisture · Mean sensitivity

\section{Introduction}

The impacts of anthropogenic climate change on the distribution and growth of tree species are likely to be severe (OcCC 2007; Parry et al. 2007). Assessing these impacts requires a good knowledge of the climatic, edaphic and synecological controls acting upon each individual species. With regard to most tree species, including European beech (Fagus sylvatica), there is insufficient knowledge on the factors that determine the natural distribution limits (cf. Chauchard et al. 2007). The drought response of beech is likely to play a major role in its future presence and persistence at lower altitudes in Central Europe (Gessler et al. 2007) and is thus the main focus of this paper. 
Drought may affect beech in the short term by causing early leaf fall, as occurred in 2003 (Rennenberg et al. 2006; Zingg and Brang 2003). It is unclear, however, whether such early leaf fall indicates a lack of adaptation to drought in the longer term. According to species distribution models (e.g. Brzeziecki et al. 1995; Zimmermann et al. 2006), it is projected that beech will retreat to higher altitudes, i.e. it will lose its dominance in the sub-montane and lower montane zones where more drought-tolerant species will take its place. In contrast, studies using dynamic forest models (Bugmann 1997; Bugmann and Pfister 2000; Rasche et al. 2012) suggest that beech will remain dominant at lower elevations in a warmer climate as long as summer precipitation does not decrease dramatically. These differing projections indicate that (1) it may become difficult for forest managers to identify appropriate management strategies under a changing climate, and (2) more detailed information on the behaviour of tree species under climate change is needed.

The radial growth of trees is affected by drought well before shifts in species composition occur (Leuzinger et al. 2005; Zimmermann et al. 2006). Thus, tree-rings are particularly suitable for studying changes at the dry distribution limits of tree species because growth responses to extremely dry years can be analysed retrospectively (Kienast et al. 1987; Rigling et al. 2002; Schweingruber 1990; Z'Graggen 1992). In dry years, such as in 2003, the productivity of many tree species including beech was found to be significantly reduced (Ciais et al. 2005; Jolly et al. 2005). Due to this immediate reaction of tree growth to drought, tree-rings can be used to monitor how a certain tree species reacts to short- and long-term changes in the regional climate with respect to local site conditions (e.g. Kienast et al. 1987; Rigling et al. 2002; Weber et al. 2007). Changes in radial growth patterns may thus act as early indicators of climate change (Fritts 1976), in analogy to changes in phenological patterns (e.g. Defila and Clot 2001; Menzel 2000). It has also been shown that soil properties may contribute significantly to explaining differences in the response of tree growth to drought (Lebourgeois et al. 2005; Rigling et al. 2001; Weber et al. 2007) in the sense that "drought is a complex edaphicclimatic factor" (Gärtner et al. 2008).

The aim of this study was to evaluate the drought response of beech near its current dry distribution limit in different climatic regions and with respect to different soil moisture conditions. We hypothesise that (1) under given climatic conditions, trees on sites with a lower available water capacity (AWC) show a greater site sensitivity and have, at the same time, a lower growth rate than trees at sites with higher AWC; (2) the pattern of drought response is more pronounced at dry sites than at mesic sites. However, we also expect that (3) these patterns are modified by climatic changes at both dry and mesic sites. We assess a combination of dendroecological methods to test these hypotheses.

\section{Materials and methods}

\section{Study sites}

The sampling design included three pairs of sites, consisting of a dry and a mesic site each. The three pairs were located in different geographical regions in Switzerland (Fig. 1, coordinates in Pluess and Weber 2012). One pair was located in the inner-alpine dry valley Valais (Vétroz: $\operatorname{VETd}=$ dry and VETm $=$ mesic), one pair in the northwest of Switzerland in the Jura region (Bärschwil: BAEd $=$ dry and BAEm $=$ mesic) and the last pair in the north of Switzerland in the comparably dry Klettgau region (Neunkirch: NEUd $=$ dry and NEUm $=$ mesic). These pairs of sites were chosen for their proximity to the dry distribution limit of beech, whereby beech at the dry site exhibited drought limitation in its morphology and occurred mixed with more drought-adapted tree species such as Pinus sylvestris and/or Quercus petraea. The Valais site was located close to the current climatic rear edge of beech (cf. Fig. 1), whereas the Bärschwil and Neunkirch sites are limited in moisture by a combination of high evapo-transpiration due to their South exposure and the comparably low water-holding capacity of the soil. At mesic sites, beech was the only tree species present. The two single sites per pair were chosen to be in close vicinity to each other (distance $<1,000 \mathrm{~m}$ ) so that both had similar regional climates, but soil that differed in its water holding capacity. They also differed in aspect (SW vs. N in Neunkirch, S vs. $\mathrm{N}$ in Bärschwil) and in topography (ridge vs. slope in Bärschwil) (cf. Table 1). At each of the six sites, ten dominant sampling trees were chosen. Position, tree height and diameter at breast height (DBH) were measured. For tree-ring analysis, two cores were extracted at $1 \mathrm{~m}$ stem height at an angle of $120^{\circ}$ so as to avoid any effects of eccentricity.

Field capacity and available water capacity of the soil (AWC) were estimated by analysing a soil profile from each site in terms of soil texture (content of sand, silt and clay), bulk density, content of coarse fragments $(>2 \mathrm{~mm}$ ) and depth of each of the recorded soil horizons according to AG Bodenkunde (1982) (Table 1). We used spatially interpolated climate data from the DAYMET model (Thornton et al. 1997) for each site. The model interpolates climate data from MeteoSwiss stations at given coordinates based on the digital height model $(100 \mathrm{~m}$ grid size). A monthly drought index (DRI) was calculated as the difference between precipitation and potential 


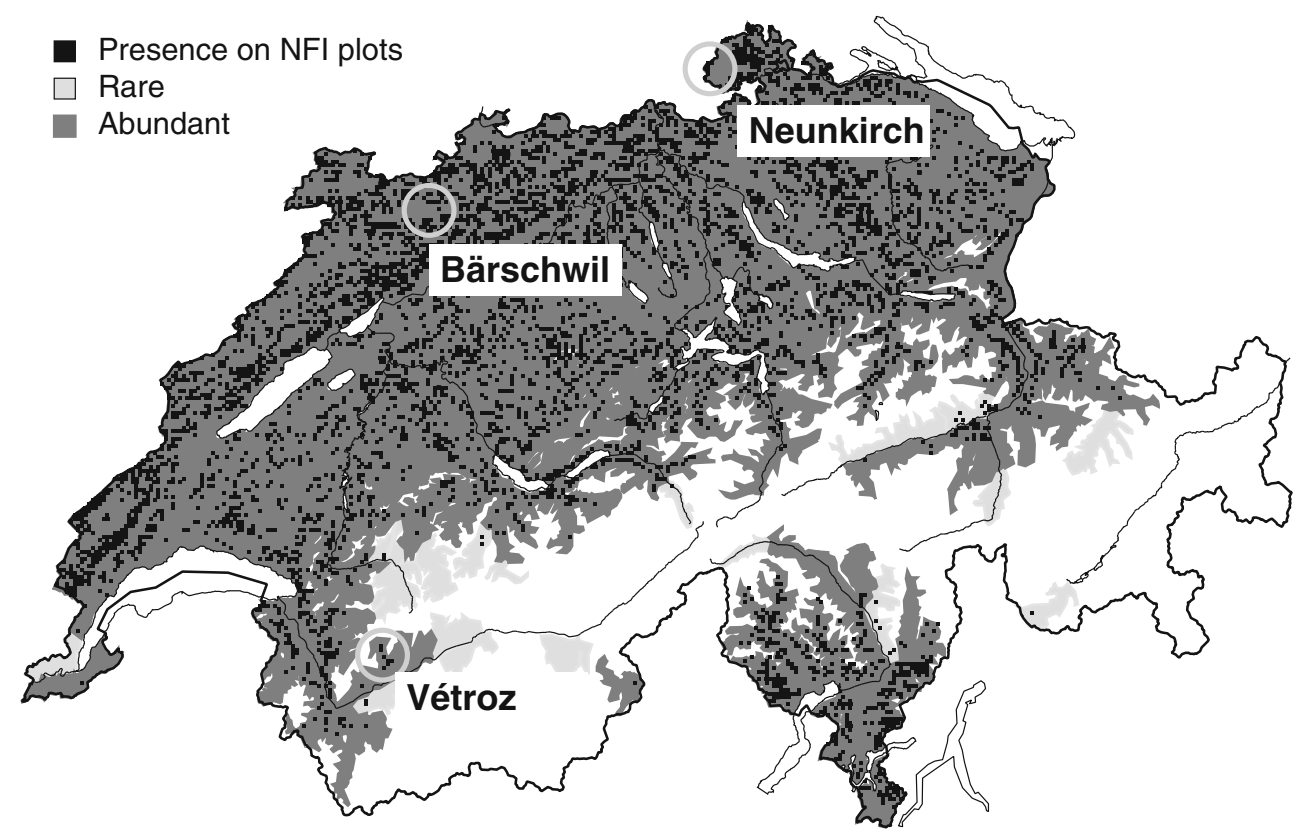

Fig. 1 Location of the three study pairs in Switzerland at Neunkirch, Bärschwil and Vétroz. The map shows the distribution of beech according to Brändli (1998). Current distribution (presence of beech on National Forest Inventory sample plots, black dots) conforms more or less to the natural distribution according to Welten and Sutter (1982) (grey areas)

Table 1 Characteristics of the sampling sites sorted according to available field capacity (AWC)

\begin{tabular}{|c|c|c|c|c|c|c|c|}
\hline & $\mathrm{AWC}(\mathrm{mm})$ & $\mathrm{FC}(\mathrm{mm})$ & Precip (mm) & Tave $\left({ }^{\circ} \mathrm{C}\right)$ & DRI (mm) & Elevation (m a.s.1.) & Aspect - \\
\hline BAEd & 26 & 40 & 1,163 & 8.06 & 597 & 700 & S \\
\hline VETd & 40 & 70 & 1,199 & 5.43 & 841 & 1,280 & SW \\
\hline NEUd & 46 & 127 & 1,016 & 8.19 & 438 & 530 & SW \\
\hline NEUm & 48 & 134 & 1,000 & 8.24 & 517 & 570 & $\mathrm{~N}$ \\
\hline BAEm & 61 & 136 & 1,206 & 7.81 & 703 & 670 & $\mathrm{~N}$ \\
\hline VETm & 79 & 126 & 1,164 & 5.70 & 824 & 1,250 & SW \\
\hline
\end{tabular}

Climatic data sums and averages were calculated for the norm period 1961-1990 using DAYMET data (Thornton et al. 1997)

evapotranspiration according to Turc (1963) to capture the combined effects of precipitation and temperature.

\section{Data analysis}

Tree-ring widths of the two cores per beech tree were measured with a resolution of $0.01 \mathrm{~mm}$ on a LINTAB (RINNTECH, Germany) measuring device. Crossdating was done both visually and based on the statistical values (e.g. cross-date index) with the program TSAP-Win (RINNTECH, Germany). We calculated robust bi-weight mean chronologies from the raw data (raw chronology) and from detrended tree-ring series (standard and residual chronologies) using the software ARSTAN (Cook 1985; Holmes 1994), whereby a cubic spline of $50 \%$ frequency response of $50 \%$ of the series length was applied for detrending. This approach seems feasible since $80 \%$ of the series were between 110 and 160 years long. Besides tree- ring width, we also calculated basal area increment (BAI), because this variable is less biased by stem geometry (Biondi and Qeadan 2008; Weber et al. 2008). Statistical indices were used to ensure the quality of the chronologies was high enough, e.g. mean rbar (cross-correlation between single series) and EPS (expressed population signal, Wigley et al. 1984), a measure of how well single series represent the whole population. Differences between dry and mesic sites in the tree's mean annual growth, age and height were tested by Analysis of Variance (ANOVA) nested for soil moisture, and differences between the dry and mesic plots within a site by unpaired $t$ tests using the statistics software R (R Development Core Team 2008).

For dendroecological investigations, a range of raw data statistical indices can be used to evaluate not only the sensitivity of tree radial growth to limiting factors, but also lag-effects due to tree internal resources, i.e. carbon reserves stored in the previous year. Sensitivity of growth 
can be defined by the percentage of variability in annual growth from 1 year to the next, whereby mean sensitivity at a site can be calculated starting from tree individual series (MSs) or based on the raw chronology (MSc). Schulman (1956) introduced a parameter for quality assessment in dendroclimatology called "Edmund Schulman's R" (ESR), the coefficient between MSc and MSs. The stronger the common signals in the single series are, i.e. the more they are limited by the same factor(s), the larger ESR is. Here, we compare the ESR parameter with the simpler MSs, which has often been criticised, either because of being a composite of autocorrelation and standard deviation (Jansma 1995) or its species-dependency and weak prediction of climate signal strength (Cook and Pederson 2011). We correlated the two sensitivity variables MSs and ESR with the other chronology variables EPS, rbar, standard deviation and first-order autocorrelation to evaluate their informative value for dendroecological studies at the dry distribution limit of a species.

A nine-year moving average was calculated from annual radial growth (raw chronology) and plotted together with the nine-year moving average of mean sensitivity (MSc). The moving average is commonly used in time-series analysis to smooth the curves. We calculated the average for 9 years in a shifting window across the whole period of analysis.

Identifying the bioclimatic controls on the ranges of plant species has become almost a standard procedure (cf. Sykes et al. 1996), and growth-climate relationships of tree species are routinely studied along altitudinal and longitudinal gradients (Di Filippo et al. 2007; Piovesan et al.
2005). We used standard procedures to statically assess the growth response of beech to drought by means of calculating response functions (Fritts 1971) with principal components of monthly drought indices (DRI) as explanatory variables and standard growth chronologies as dependent variables. In addition, we used the software DENDROCLIM (Biondi and Waikul 2004) to compute moving response functions in a 30-year window, which allowed dynamical changes in the drought response pattern to be detected across time.

Pointer year analysis captures the temporal distribution of extreme years (narrow or wide rings) in radial growth. We analysed pointer years from raw tree-ring width series according to Cropper (1979), i.e. years that differed notably from the normalised mean growth value within a 5-year moving window. The threshold to retrieve negative and positive pointer years was set at a cropper value of 0.8 (Cropper 1979; Meyer 1999). Positive and negative pointer years were summarised for each site over three 25-year long periods (1930-1954, 1955-1979, 1980-2004) and the site total number of pointer years was counted for the whole period of analysis from 1930 to 2004 .

\section{Results}

Chronology statistics and growth characteristics

All tree-ring chronologies were of good statistical quality (Table 2, EPS and rbar). Thus, we were able to use a range of simple statistical properties based on the raw data to

Table 2 Statistical properties of the raw tree-ring series for the three pairs of sites for the common period 1930-2006

\begin{tabular}{|c|c|c|c|c|c|c|}
\hline & BAR & BAT & NES & NEN & VEF & VET \\
\hline Mean TRW (mm) & 1.049 & 1.944 & 0.998 & 1.924 & 1.093 & 1.093 \\
\hline Standard deviation TRW & 0.209 & 0.231 & 0.236 & 0.210 & 0.217 & 0.194 \\
\hline Mean BAI $\left(\mathrm{cm}^{2}\right)$ & 7.82 & 24.33 & 9.44 & 27.99 & 8.79 & 10.39 \\
\hline Mean Sensitivity (MSs) & 0.291 & 0.222 & 0.259 & 0.279 & 0.294 & 0.253 \\
\hline ESR (=MSc/MSs) & 0.806 & 0.659 & 0.699 & 0.752 & 0.795 & 0.685 \\
\hline 1st order Autocorrelation & 0.657 & 0.597 & 0.700 & 0.560 & 0.550 & 0.608 \\
\hline Mean rbar & 0.354 & 0.258 & 0.310 & 0.433 & 0.425 & 0.400 \\
\hline EPS & 0.916 & 0.884 & 0.895 & 0.939 & 0.934 & 0.930 \\
\hline Number of trees & 10 & 11 & 10 & 10 & 10 & 10 \\
\hline Number of cores & 20 & 22 & 19 & 20 & 19 & 20 \\
\hline Mean age (years) & 132 & 118 & 139 & 133 & 150 & 159 \\
\hline Maximum age (years) & 138 & 121 & 174 & 159 & 235 & 196 \\
\hline Minimum age (years) & 125 & 114 & 105 & 115 & 93 & 125 \\
\hline Mean height (m) & 17 & 41 & 21 & 30 & 13 & 30 \\
\hline Mean DBH (cm) & 28 & 49 & 36 & 57 & 34 & 38 \\
\hline
\end{tabular}

Average annual growth [tree-ring width (TRW) and basal area increment (BAI)], number of samples, age distribution, mean height and dbh of the sampling trees on each plot 
Fig. 2 Changes between the three study periods (25-year averages) in a mean sensitivity (MSc) over the common period and at the same time $\mathbf{b}$ the drought index during the summer months (DRI June to August)
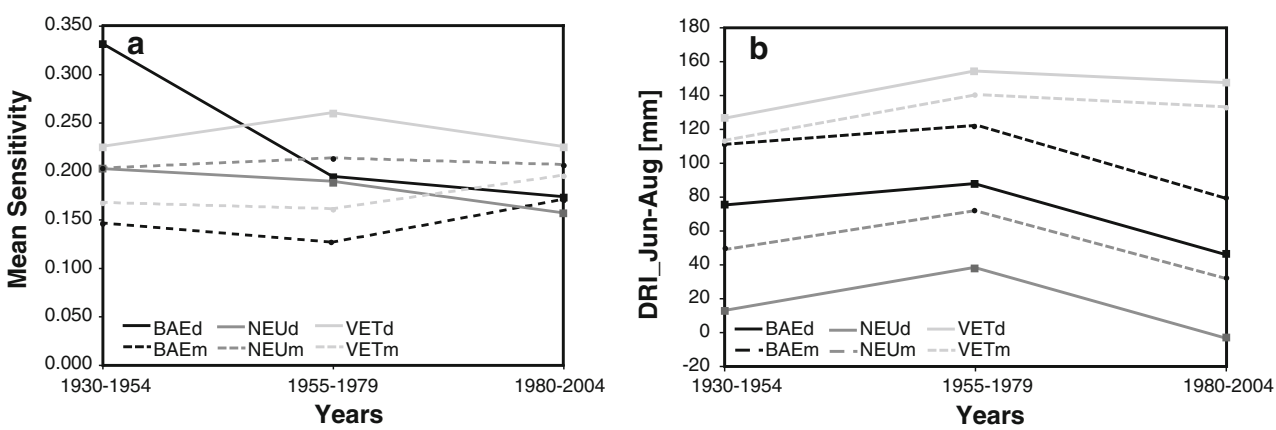

characterise the sites and compare the dry and mesic sites. The mean tree age at the sites ranged from 118 to 159 years (Table 2), but did not differ significantly (ANOVA, $P_{\mathrm{AGE}}=0.59$ ). This meant the sites could be directly compared. Apart from one tree at VETd that was 93 years old, all trees were older than 100 years, with two trees over 200 years old. The oldest trees were found at the two Vétroz sites VETd and VETm, where the maximum ages were 235 and 196 years, respectively. The lowest maximum age of around 130 years was found at the Bärschwil sites. The maximum age at the two Neunkirch sites was around 170 years, i.e. in-between that of the other sites.

No age trend, which is typically negative exponential, was visible in any of the sites during the study period (1930-2006) (cf. Fig. 3b), but the annual growth, measured as tree-ring width (TRW) and basal area increment (BAI), differed notably between dry and mesic sites (ANOVA $\left.P_{\text {TRW }}<0.001, P_{\mathrm{BAI}}<0.001\right)$. At Bärschwil and Neunkirch, mean TRW of the two dry sites was around $1 \mathrm{~mm}$ per year and about half as large as the tree-ring width of their corresponding mesic sites (Table 2, $t$ test both pairs $p<0.001$ ); BAI was even approximately three times smaller at dry than at mesic sites (both pairs $p<0.001$ ). At Vétroz, mean TRW ( $t$ test $p=0.54)$ and BAI $(p=0.18)$ at the dry and the mesic site were not significantly different. The mean tree heights of the ten dominant trees per plot differed clearly between the dry and mesic sites (ANOVA, $\left.P_{\text {HEIGHT }}<0.001\right)$. Tree heights differed most between the dry $(13 \mathrm{~m})$ and mesic $(30 \mathrm{~m})$ sites at Vétroz $(t$ test $p<0.001)$, although the trees there were rather similar in diameter and, as described above, also in age. At Bärschwil, we also found a large difference in the dominant tree height at the dry $(17 \mathrm{~m})$ and the mesic $(41 \mathrm{~m})$ site $(t$ test $p<0.001)$. At Neunkirch, trees at the dry site $(21 \mathrm{~m})$ were also significantly shorter than trees at the mesic site $(30 \mathrm{~m})$ ( $t$ test $p<0.001$ ).

\section{Mean sensitivity}

The mean sensitivity of the sites was ordered in reverse to available soil water capacity (AWC) for the first period of analysis (1930-1954) (Fig. 2a); i.e. the sites with the lowest AWC were the most sensitive. This pattern changed gradually until in the last period of the three analysed periods (1980-2004) two of the sites with low AWC (BAEd and NEUd) had the lowest sensitivity, whereas sensitivity increased slightly for the high AWC sites BAEm and VETm. At the same time, a decrease in DRI for the period June to August indicated a decrease in moisture availability at all sites north of the Alps (BAEd, BAEm, NEUd, NEUm), while moisture availability increased at the Vétroz sites (VETd, VETm) (Fig. 2b). The mean sensitivity (MSs) and the Edmund Schulman's R (ESR) correlated strongly with each other $(r=0.95)$. MSs was more strongly correlated with rbar $(r=0.73)$ and EPS $(r=0.71)$ than ESR (rbar: $r=0.58$, EPS: $r=0.58$ ). MSs and ESR did not correlate with either standard deviation $(|r|<0.4)$ or first-order autocorrelation $(|r|<0.2)$.

Looking at the 9-year moving average of mean sensitivity and tree-ring width (TRW) at the six sites (Fig. 3), we found the sensitivity trends at the sites differed across time (Fig. 3a), whereas the growth levels at the sites remained fairly constant relative to each other (Fig. 3b). This was most obvious with the Bärschwil pair of sites. While at the beginning of the common period mean sensitivity of the dry site BAEd was much higher than at the mesic site BAEm, both curves reached a similar level from the later 1970s onwards. On the other hand, tree-ring width at BAEm always remained at a level about twice as high as at BAEd. Also at the Vétroz sites, mean sensitivity did not follow the same pattern (Fig. 3a), while radial growth (TRW, Fig. 3b) was similar during the whole period of analysis. At the Neunkirch sites, mean sensitivity was similar during the first 15 years of analysis and in the early 1970s, but otherwise deviated, while the growth level always differed by approximately a factor of two.

\section{Drought response}

The six beech chronologies all showed significant response to drought mainly in the growing period from March to June (see the top boxes for each site in Table 3). Apart 

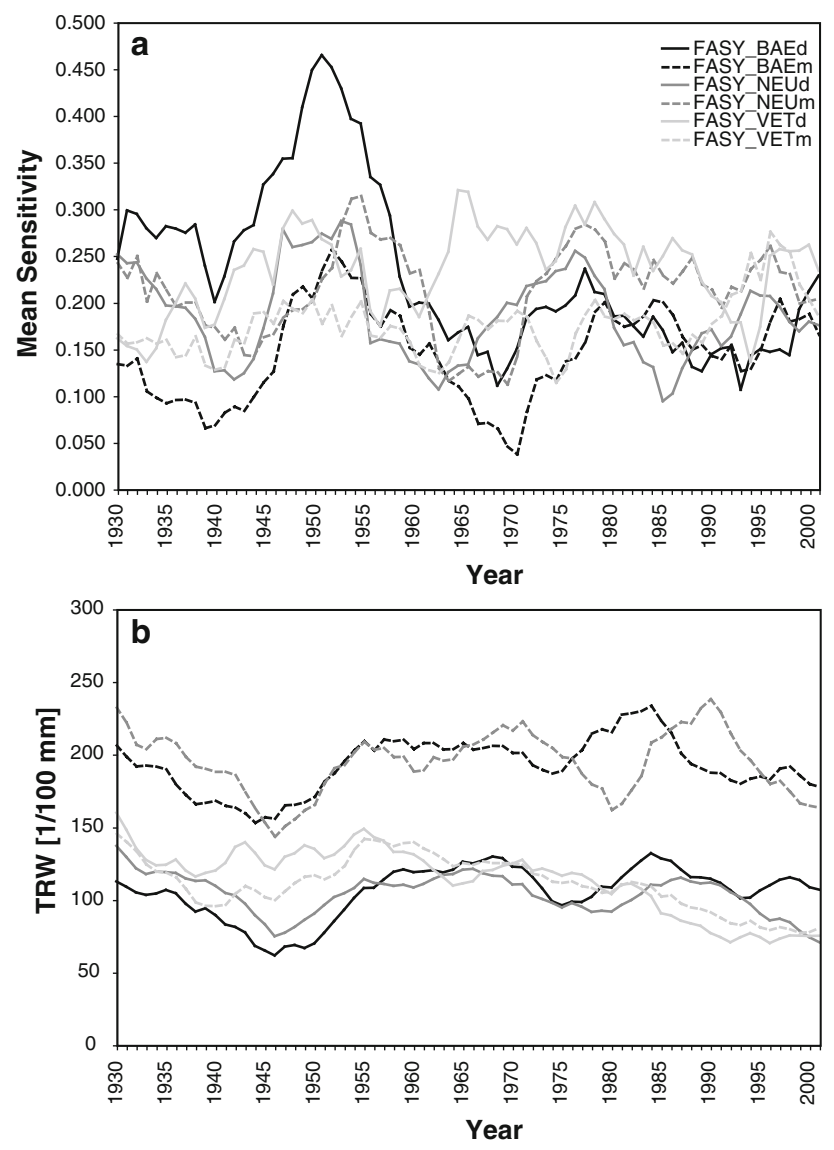

Fig. 3 Smoothed a mean sensitivity (MSc) and $\mathbf{b}$ tree-ring width for the six sites calculated as the nine-year moving average. Dry sites are shown with continuous lines, mesic sites with dashed lines; the sites at Bärschwil in black, Neunkirch in dark grey, Vétroz in light grey

from the detected positive responses to the drought index (DRI) during these 4 months, the three sites BAEd, VETd and VETm also responded significantly to the DRI in August prior to ring formation (results not shown), but besides, no other significant responses were detected around the year. Consequently, we reduced the number of months to calculate the moving response functions to the four most important months during the growing season (March through June) to reveal potential shifts in the drought response patterns over time (Table 3). We found no clear shift in the drought response at dry sites. All dry sites responded to drought in May. In addition, at the dry sites north of the Alps, March and April (the latter only at NEUd) were significant. At VETd, the higher elevated dry site in the inner-Alpine valley, June was highly significant apart from May. In contrast, changing patterns of seasonality were clearly visible at mesic sites, where the drought responses shifted towards March in BAEm and towards June in NEUm and VETm during the period of analysis. This shift took place nearly simultaneously at all mesic sites in the years between 1963 and 1973.
Pointer years

In total, negative pointer years were much more frequent at dry sites ( 24 in total) than at mesic sites (11 in total) (Table 4). In contrast, the number of positive pointer years was the same at dry and mesic sites, except for the Neunkirch pair, including the sites NEUd (4) and NEUm (10). In general, there was a tendency for pointer years to become increasingly frequent at mesic sites; this was particularly visible in the later half of the twentieth century. Negative pointer years did not occur at the mesic sites BAEm, NEUm and only one at the mesic site VETm during the first period of analysis (i.e. 2nd quarter of the twentieth century), whereas one up to three negative pointer years occurred in the two later periods. This pattern for the number of pointer years to increase was also apparent with the positive pointer years at the mesic site BAEm and to some extent at the other mesic sites NEUm and VETm. At the dry site BAEd, the frequency of both negative and positive pointer years decreased noticeably from the first two periods to the last period analysed. At the dry sites NEUd and VETd, we detected the highest number of negative pointer years in the second period, i.e. in the 3 rd quarter of the twentieth century.

\section{Discussion}

Changes in drought response and sensitivity

Combining various dendroecological methods at three pairs of sampling sites, including a mesic and dry site each, we were able to detect recent changes in the drought response and sensitivity of beech, in particular at mesic sites. Since the dry sites studied are close to the drought limit of beech, we expected the increasing limitation on growth due to climatic changes to be particularly visible at these sites. Contrary to our expectation, we found that changing sensitivity (assessed by mean sensitivity and pointer year analysis) and changes in drought response were more pronounced at mesic than at dry sites; i.e. water availability appears to place increasing limits on growth at mesic sites. Other potential factors influencing these sensitivity changes such as increasing tree age and forest management can be ruled out, since no age trend, which would be a negative exponential (cf. Fritts 1976), was visible in the tree-ring chronologies (Fig. 3) and no management interventions occurred, as for as we know, during the period of interest.

The parallel development of pointer years is another indication that the changing sensitivities are the result of site-specific changes in limiting abiotic factors. Whereas negative pointer years were generally more frequent at dry 
Table 3 Significant response coefficients from response functions for the period 1930-2005 from previous August to current September (values in top box for each site, significant response coefficients of previous August are not shown), and significant $(p<0.05)$ moving response, calculated only for March, April, May and June. For the calculation of the moving response, a 30-year window was chosen (the year indicated is in the middle of the moving window). Different colours apply for response coefficient ranges: $>0.4$, IIIIIIIII -0.25 to -0.4

\begin{tabular}{|c|c|c|c|c|c|c|c|c|c|c|c|c|c|c|}
\hline & March & April & May & June & & March & April & May & June & & March & April & May & June \\
\hline BAEd & 0.25 & 0.22 & 0.31 & & NEUd & 0.25 & & 0.30 & & VETd & & & 0.26 & 0.44 \\
\hline 1945 & & & & & 1945 & & & & & 1945 & & & & \\
\hline 1950 & & & & & 1950 & & & & & 1950 & & & & \\
\hline 1955 & & & & & 1955 & & & & & 1955 & & & & \\
\hline 1960 & & & & & 1960 & & & & & 1960 & & & & \\
\hline 1965 & & & & & 1965 & & & & & 1965 & & & & \\
\hline 1970 & & & & & 1970 & & & & & 1970 & & & & \\
\hline 1975 & & & & & 1975 & & & & & 1975 & & & & \\
\hline 1980 & & & & & 1980 & & & & & 1980 & & & & \\
\hline 1985 & & & & & 1985 & & & & & 1985 & & |IIIIIII & & \\
\hline 1990 & & & & & 1990 & & & & & 1990 & & & & \\
\hline
\end{tabular}

\begin{tabular}{|c|c|c|c|c|c|c|c|c|c|c|c|c|c|c|}
\hline & March & April & May & June & & March & April & May & June & & March & April & May & June \\
\hline BAEm & 0.28 & & 0.20 & 0.22 & NEUm & & & & 0.29 & VETm & & & & 0.25 \\
\hline 1945 & & & & & 1945 & & & & & 1945 & & & & \\
\hline 1950 & & & & & 1950 & & & & & 1950 & & & & \\
\hline 1955 & & & & & 1955 & & & & & 1955 & & & & \\
\hline 1960 & & & & & 1960 & & & & & 1960 & & & & \\
\hline 1965 & & & & & 1965 & & & & & 1965 & & & & \\
\hline 1970 & & & & & 1970 & & & & & 1970 & & & & \\
\hline 1975 & & & & & 1975 & & & & & 1975 & & & & \\
\hline 1980 & & & & & 1980 & & & & & 1980 & & & & \\
\hline 1985 & & & & & 1985 & & & & & 1985 & & & & \\
\hline 1990 & & & & & 1990 & & & & & 1990 & & & & \\
\hline
\end{tabular}


Table 4 Number of positive and negative pointer years (Cropper values) at the six sampling sites (1900-2004)

\begin{tabular}{lcccccc}
\hline & BAEd & BAEm & NEUd & NEUm & VETd & VETm \\
\hline $\begin{array}{l}\text { Positive pointer years }(>0.8) \\
\text { 1930-1954 }\end{array}$ & 4 & 1 & 1 & 2 & 4 & 3 \\
$1955-1979$ & 5 & 4 & 2 & 5 & 1 & 2 \\
$1980-2004$ & 1 & 5 & 1 & 3 & 5 & 5 \\
Total & 10 & 10 & 4 & 10 & 10 & 10 \\
$(1930-2004)$ & & & & & & \\
Negative pointer years $(<-0.8)$ & & & & \\
$1930-1954$ & 5 & 0 & 2 & 0 & 2 & 1 \\
$1955-1979$ & 3 & 1 & 3 & 2 & 4 & 1 \\
$1980-2004$ & 1 & 1 & 2 & 2 & 2 & 3 \\
Total & 9 & 2 & 7 & 4 & 8 & 5 \\
$(1930-2004)$ & & & & & & \\
\hline
\end{tabular}

Counted are pointer years with a Cropper value above/below $0.8 /-0.8$

sites than at mesic sites, there was a tendency for negative and positive pointer years to increase at mesic sites. In their study on changing growth patterns of Iberian pine forests, Andreu et al. (2007) found that the development of mean sensitivity and pointer years had a similar coherence.

Implications of increased response at mesic sites

Our findings introduce a novel point of view into the ongoing debate on tree response to climate change, suggesting that tree radial growth patterns and thus forest productivity may change significantly also at the ecological optimum of a species and not only at the species range limits. It is known from phenological studies that bud burst in beech occurs earlier in years with higher mean annual temperatures (Menzel et al. 2006). As a consequence of this, trees can be expected to respond to moisture availability earlier in the year, which has unknown consequences on radial growth. Our results provide a clear indication that mean sensitivity and drought response of beech trees are also changing at mesic sites where beech trees grow well. In accordance with our results, Scharnweber et al. (2011) found the sensitivity of beech increased and negative pointer years became more frequent on humid sites along an east-west precipitation gradient in Germany. Newly emerging patterns of drought response at "wetter" beech sites were also detected for recent decades by Friedrichs et al. (2009). In contrast, at the southern distribution limit of beech, growth changes have become evident at dry sites, for example, growth has decreased at the range-edge in the Montseny Mountains in Catalonia (Spain), even though intrinsic water-use efficiency appears to increase under continuously rising atmospheric $\mathrm{CO}_{2}$
(Penuelas et al. 2008). Also, growth has decreased under long-term drought stress in the central Apennines (Italy) (Piovesan et al. 2008).

The influence of site conditions on beech growth patterns

Overall, tree-ring growth at dry sites clearly differed from that at mesic sites in both the growth level and the seasonal response to moisture availability. Mean growth at dry sites was twice that at mesic sites in the pairs North of the Alps despite the fact that the stands were of comparable age. This demonstrates the great influence of site conditions on tree growth, which was also apparent in the large differences $(9-24 \mathrm{~m})$ in the average tree height of the ten dominant sampling trees at dry and mesic sites. As hypothesised, the overall pattern of drought response across the whole period of analysis was more pronounced at dry sites, but the same months were not always significant at all dry sites, pointing to additional local influences. Comparing our statistical chronology parameters with those from a study on the bioclimatology of beech in the Eastern Alps (Di Filippo et al. 2007), we found that our MSs was medium to high (0.222-0.294), whereas 1st-order autocorrelation was medium $(0.550-0.700)$ and standard deviation was comparably low (0.194-0.236). For the first 25 -year period of analysis, the mean sensitivity of the sites was related inversely to soil AWC. However, although this pattern fits the theoretical expectation of stronger sensitivity at more limiting conditions, the pattern seemed to have disappeared in the later periods of analysis, when the mean sensitivity at the dry sites BARd and NEUd decreased in parallel with an increase at the mesic sites BARm and VETm.

Mean sensitivity as a dendroecological measure of growth limitation

The value of using mean sensitivity as a variable to assess the sensitivity of growth to limiting factors such as climate is controversial (Cook and Pederson 2011; Jansma 1995), but we thought a re-evaluation for dendroecological studies was called for. We found that MSs correlated more strongly with the two frequently used measures of chronology strength (rbar and EPS) than ESR, which is a measure originally introduced by Schulman (1956) for dendroclimatological studies. The relatively high correlation coefficients also indicate that mean sensitivity can indeed be used as (an additional) parameter to assess climate sensitivity, when comparing chronologies from different sites, but originating from the same tree species. Unlike Jansma (1995), we found that MSs and ESR were not correlated with either standard deviation or first-order 
autocorrelation. We recommend using raw tree-ring data to calculate these statistical parameters as a measure for site sensitivity. First-order autocorrelation and MSs have also been shown, when used in combination, to provide a powerful tool to assess changing forest conditions (Beck and Müller 2006).

Choice of sampling sites and genetic differentiation

To reveal changes in the growth behaviour of beech close to the dry distribution limit, we designed the study to include three pairs of sites from different geographical regions in Switzerland. The Vétroz pair of sites differed from the other two pairs, in that the drought responses at the dry and mesic sites were much more similar to each other than was the case at Bärschwil and Neunkirch. One reason for this discrepancy could be that Vétroz is located in the inner-Alpine dry valley Valais, i.e. closer to the climatic limit of beech (Pott 2000). In the pairs North of the Alps, the differences in topographic aspect may also play a role for the different growth responses at dry and mesic plots (Fekedulegn et al. 2003). In comparison with many other dendroecological studies, our approach put the focus on soil properties right from the beginning. With the chosen sampling design of dry and mesic sites, we were indeed able to confirm that drought limitation in beech has both a strong edaphic and climatic component (cf. Gärtner et al. 2008). The additional parallel study on genetic variation in the same beech stands revealed differentiation at dry versus mesic sites in potentially adaptive genetic markers, indicating that similar selection pressures acted at dry versus mesic sites across regions (Pluess and Weber 2012).

If radial growth patterns can be used as early indicators of mortality (Bigler and Bugmann 2004), then our results should contribute to a better projection of future growth and species composition of the lower beech ranges in Central Europe. However, this evaluation of growth patterns should be further extended to include e.g. competitor tree species. Moreover, data on regeneration and mortality, which are more difficult to assess retrospectively, need to be taken into account.

\section{Conclusions}

We found clear differences in the growth patterns of beech trees on dry and mesic sites. Growth was much smaller at dry sites where at the same time the response to drought was stronger. Indeed, mean sensitivity was inversely related to soil AWC in the first quarter of the period analysed. However, we also revealed changing sensitivity and drought response patterns of beech under climatic changes, in particular at mesic sites. The increasing frequency of pointer years coincided with the increasing mean sensitivity and changing seasonality of drought response. This suggests that, at mesic sites, recent changes to climatically more limiting conditions have affected the growth of trees more strongly than at dry sites where trees are probably already growing at the limit. Accordingly, a negative impact on future forest resources has to be expected also at productive sites.

Acknowledgments We would like to thank Hannes Suter and Daniel Bernet for their help with sampling and measuring tree cores, as well as Roger Köchli, Marco Walser, Pascal Wiesli and Roger Schürmann for their help with the soil pits. DAYMET climate data were provided by Dirk Schmatz. We are grateful to two anonymous referees who provided valuable comments and to Silvia Dingwall who helped with language editing. This work was funded by the Swiss State Secretariat for Education and Research (SER) as part of a project within COST Action E52 on beech genetics (SBF grant No. C07.0113), and by the Swiss Federal Office for the Environment (FOEN).

\section{References}

Andreu L, Gutierrez E, Macias M, Ribas M, Bosch O, Camarero JJ (2007) Climate increases regional tree-growth variability in Iberian pine forests. Glob Change Biol 13:804-815

Beck W, Müller J (2006) Impact of heat and drought on tree and stand vitality-dendroecological methods and first results from level II-plots in southern Germany. Schriften aus der Forstlichen Fakultät der Universität Göttingen und der Nordwestdeutschen Forstlichen Versuchsanstalt 142:120-127

Bigler C, Bugmann H (2004) Predicting the time of tree death using dendrochronological data. Ecol Appl 14:902-914

Biondi F, Qeadan F (2008) A theory-driven approach to tree-ring standardization: defining the biological trend from expected basal area increment. Tree Ring Res 64:81-96

Biondi F, Waikul K (2004) DENDROCLIM2002: a C++ program for statistical calibration of climate signals in tree-ring chronologies. Comput Geosci 30:303-311

Bodenkunde AG (1982) Bodenkundliche Kartieranleitung. Schweizerbart, Stuttgart, p 331

Brändli U-B (1998) Die häufigsten Waldbäume der Schweiz. Ergebnisse aus dem Landesforstinventar 1983-85: Verbreitung, Standort und Häufigkeit von 30 Baumarten. Eidg. Forschungsanstald für Wald, Schnee und Landschaft, Birmensdorf, p 279

Brzeziecki B, Kienast F, Wildi O (1995) Modeling potential impacts of climate-change on the spatial distribution of zonal forest communities in Switzerland. J Veg Sci 6:257-268

Bugmann H (1997) Sensitivity of forests in the European Alps to future climatic change. Clim Res 8:35-44

Bugmann H, Pfister C (2000) Impacts of interannual climate variability on past and future forest composition. Reg Environ Change 1:112-125

Chauchard S, Carcaillet C, Guibal F (2007) Patterns of land-use abandonment control tree-recruitment and forest dynamics in Mediterranean mountains. Ecosystems 10:936-948

Ciais P, Reichstein M, Viovy N, Granier A, Ogee J, Allard V, Aubinet M, Buchmann N, Bernhofer C, Carrara A, Chevallier F, De Noblet N, Friend AD, Friedlingstein P, Grunwald T, Heinesch B, Keronen P, Knohl A, Krinner G, Loustau D, Manca G, Matteucci 
G, Miglietta F, Ourcival JM, Papale D, Pilegaard K, Rambal S, Seufert G, Soussana JF, Sanz MJ, Schulze ED, Vesala T, Valentini R (2005) Europe-wide reduction in primary productivity caused by the heat and drought in 2003. Nature 437:529-533

Cook ER (1985) A time series analysis approach to tree-ring standardization. Department of Geosciences. University of Arizona, Tucson, Arizona, USA, p 171

Cook ER, Pederson N (2011) Uncertainty, emergence, and statistics in dendrochronology. In: Hughes MK, Swetnam TW, Diaz HF (eds) Dendroclimatology. Developments in paleoenvironmental research, vol 11. Springer, Berlin, pp 77-112

Cropper JP (1979) Tree-ring skeleton plotting by computer. Tree Ring Bull 39:47-59

Defila C, Clot B (2001) Phytophenological trends in Switzerland. Int J Biometeorol 45:203-207

Di Filippo A, Biondi F, Cufar K, de Luis M, Grabner M, Maugeri M, Presutti Saba E, Schirone B, Piovesan G (2007) Bioclimatology of beech (Fagus sylvatica L.) in the Eastern Alps: spatial and altitudinal climatic signals identified through a tree-ring network. J Biogeogr 34:1873-1892

Fekedulegn D, Hicks RR, Colbert JJ (2003) Influence of topographic aspect, precipitation and drought on radial growth of four major tree species in an Appalachian watershed. For Ecol Manage 177:409-425

Friedrichs D, Trouet V, Büntgen U, Frank D, Esper J, Neuwirth B, Löffler J (2009) Species-specific climate sensitivity of tree growth in Central-West Germany. Trees 23:729-739

Fritts HC (1971) Multivariate techniques for calibrating time series used to reconstruct anomalies in paleoclimate. Bull Am Meteorol Soc 52:218

Fritts HC (1976) Tree rings and climate. Academic Press, London

Gärtner S, Reif A, Xystrakis F, Sayer U, Bendagha N, Matzarakis A (2008) The drought tolerance limit of Fagus sylvatica forest on limestone in southwestern Germany. J Veg Sci 19:757-768

Gessler A, Keitel C, Kreuzwieser J, Matyssek R, Seiler W, Rennenberg H (2007) Potential risks for European beech (Fagus sylvatica $\mathrm{L}$.) in a changing climate. Trees 21:1-11

Holmes RL (1994) Computer-assisted quality control in tree-ring dating and measurement. Tree Ring Bull 43:69-78

Jansma E (1995) RemembeRINGs: the development and application of local and regional tree-ring chronologies of oak for the purposes of archaeological and historical research in the Netherlands. Dissertation, Universiteit van Amsterdam. Rijksdienst voor het Oudheidkundig Bodemonderzoek. Amersfoort

Jolly WM, Dobbertin M, Zimmermann NE, Reichstein M (2005) Divergent vegetation growth responses to the 2003 heat wave in the Swiss Alps. Geophys Res Lett 32:L18409. doi: 10.1029/2005GL023252

Kienast F, Schweingruber FH, Bräker OU, Schaer E (1987) Tree-ring studies on conifers along ecological gradients and the potential of single-year analyses. Can J For Res 17:683-696

Lebourgeois F, Breda N, Ulrich E, Granier A (2005) Climate-treegrowth relationships of European beech (Fagus sylvatica L.) in the French Permanent Plot Network (RENECOFOR). Trees 19:385-401

Leuzinger S, Zotz G, Asshoff R, Körner C (2005) Responses of deciduous forest trees to severe drought in Central Europe. Tree Physiol 25:641-650

Menzel A (2000) Trends in phenological phases in Europe between 1951 and 1996. Int J Biometeorol 44:76-81

Menzel A, Sparks TH, Estrella N, Koch E, Aasa A, Ahas R, AlmKubler K, Bissolli P, Braslavska O, Briede A, Chmielewski FM, Crepinsek Z, Curnel Y, Dahl A, Defila C, Donnelly A, Filella Y, Jatcza K, Mage F, Mestre A, Nordli O, Penuelas J, Pirinen P, Remisova V, Scheifinger H, Striz M, Susnik A, Van Vliet AJH,
Wielgolaski FE, Zach S, Zust A (2006) European phenological response to climate change matches the warming pattern. Glob Change Biol 12:1969-1976

Meyer FD (1999) Pointer years analysis in dendroecology: a comparison of methods. Dendrochronologia 16-17:193-204

OcCC (2007) Klimaänderung und die Schweiz. Erwartete Auswirkungen auf Umwelt, Gesellschaft und Wirtschaft, p 168

Parry ML, Canziani OF, Palutikof JP, van der Linden PJ, Hanson CE (eds) (2007) Contribution of Working Group II to the Fourth Assessment Report of the Intergovernmental Panel on Climate Change. Cambridge University Press, Cambridge, p 976

Penuelas J, Hunt JM, Ogaya R, Jump AS (2008) Twentieth century changes of tree-ring $\delta 13 \mathrm{C}$ at the southern range-edge of Fagus sylvatica: increasing water-use efficiency does not avoid the growth decline induced by warming at low altitudes. Glob Change Biol 14:1076-1088

Piovesan G, Biondi F, Bernabei M, Di Filippo A, Schirone B (2005) Spatial and altitudinal bioclimatic zones of the Italian peninsula identified from a beech (Fagus sylvatica L.) tree-ring network. Acta Oecologica 27:197-210

Piovesan G, Biondi F, Di Filippo A, Alessandrini A, Maugeri M (2008) Drought-driven growth reduction in old beech (Fagus sylvatica L.) forests of the central Apennines, Italy. Glob Change Biol 14:1265-1281

Pluess AR, Weber P (2012) Drought-adaptation potential in Fagus sylvatica: linking moisture availability with genetic diversity and dendrochronology. PLoS One 7:e33636. doi:33610.31371/ journal.pone. 0033636

Pott R (2000) Palaeoclimate and vegetation-long-term vegetation dynamics in central Europe with particular reference to beech. Phytocoenologia 30:285-333

R Development Core Team (2008) R: a language and environment for statistical computing. R Foundation for Statistical Computing, Vienna, Austria. http://cran.r-project.org/

Rasche L, Fahse L, Zingg A, Bugmann H (2012) Enhancing gap model accuracy by modeling dynamic height growth and dynamic maximum tree height. Ecol Model 232:133-143

Rennenberg H, Loreto F, Polle A, Brilli F, Fares S, Beniwal RS, Gessler A (2006) Physiological responses of forest trees to heat and drought. Plant Biol 8:556-571

Rigling A, Waldner PO, Forster T, Bräker OU, Pouttu A (2001) Ecological interpretation of tree-ring width and intraannual density fluctuations in Pinus sylvestris on dry sites in the central Alps and Siberia. Can J For Res 31:18-31

Rigling A, Bräker OU, Schneiter G, Schweingruber F (2002) Intraannual tree-ring parameters indicating differences in drought stress of Pinus sylvestris forests within the Erico-Pinion in the Valais (Switzerland). Plant Ecol 163:105-121

Scharnweber T, Manthey M, Criegee C, Bauwe A, Schroeder C, Wilmking M (2011) Drought matters-declining precipitation influences growth of Fagus sylvatica L. and Quercus robur L. in north-eastern Germany. For Ecol Manage 262:947-961

Schulman E (1956) Dendroclimatic changes in semiarid America. University of Arizona Press, Tucson

Schweingruber F (1990) Identification, presentation and interpretation of event years and pointer years in dendrochronology. Dendrochronologia 8:9-38

Sykes MT, Prentice IC, Cramer W (1996) A bioclimatic model for the potential distributions of north European tree species under present and future climates. J Biogeogr 23:203-233

Thornton PE, Running SW, White MA (1997) Generating surfaces of daily meteorological variables over large regions of complex terrain. J Hydrol 190:214-251

Turc L (1963) Evaluation des besoins en eau d'irrigation, évapotranspiration potentielle, formulation simplifié et mise à jour. Ann Agron 12:13-49 
Weber P, Bugmann H, Rigling A (2007) Radial growth responses to drought of Pinus sylvestris and Quercus pubescens in an innerAlpine dry valley. J Veg Sci 18:777-792

Weber P, Bugmann H, Fonti P, Rigling A (2008) Using a retrospective dynamic competition index to reconstruct forest succession. For Ecol Manage 254:96-106

Welten M, Sutter R (1982) Verbreitungsatlas der Farn- und Blütenpflanzen der Schweiz. Birkhäuser, Basel, p 716

Wigley TML, Briffa KR, Jones PD (1984) On the average value of correlated time-series, with applications in dendroclimatology and hydrometeorology. J Clim Appl Meteorol 23:201-213
Z'Graggen S (1992) Dendrohistometrisch-klimatologische Untersuchung an Buchen (Fagus silvatica L.). Philosophisch-Naturwissenschaftliche Fakultät, vol. PhD, Universität Basel, Basel, p 167

Zimmermann NE, Bolliger J, Gehrig-Fasel J, Guisan A, Kienast F, Lischke H, Rickebusch S, Wohlgemuth T (2006) Wo wachsen die Bäume in 100 Jahren? Forum für Wissen: 63-71

Zingg A, Brang P (2003) Zuwachs von Buchen nach Trockenjahren. Sterben Buchen wegen der Trockenheit? Wald und Holz 9:44-46 